\title{
TYPEWRITER TO COMPUTER - FIFTY YEARS OF THE NEW ZEALAND PLANT PROTECTION SOCIETY'S PUBLICATIONS
}

\author{
J.F. PEARSON \\ Grasslands, AgResearch, PO Box 60, Lincoln
}

\begin{abstract}
The first National Weeds Conference was held in 1948 at Lincoln College and subsequent conferences were situated at 19 venues throughout New Zealand. In 1950, the Committee decided to publish the proceedings, which encouraged participation and growth of the Society. Quality presentations were assured with the creation of an editorial position and backup from a referee panel. The 50 volumes have provided an insight into the Society's advances into modern publishing, with regular contributing authors. This review traces the history and publication record of the New Zealand Plant Protection Society and its communication of research findings.
\end{abstract}

Keywords: history, editors, publications, computer technology

\section{INTRODUCTION}

Allied forces required food in the Pacific during World War II (US Joint Purchasing Board 1945) and New Zealand's agricultural production was extended to its limits to meet this demand. There were shortages of both manpower and farm equipment as a result of the war effort. The return of servicemen from overseas marked a turning point in New Zealand's agricultural production. Neglected farm equipment was replaced, resulting in the tripling of farm tractor sales by 1950 (Robinson 1989). Aerial topdressing of fertiliser to millions of hectares of previously inaccessible hill country resulted in improved pasture, farm production and revenue. Farmers were prepared to accept changes in farming practices once they were convinced of the value of the new methods and/or technology.

Dan Watkins was only 25 when he returned from the war and, with his brother, entered into partnership to form an agricultural chemical company called Ivon Watkins Limited in New Plymouth. It was Dan Watkin's foresight and enthusiasm that inspired the first National Weeds Conference in 1948, a forerunner to the New Zealand Weed Conference, the New Zealand Weed and Pest Control Conference and the present New Zealand Plant Protection Conference.

\section{Conference venues}

The early annual conferences were held each winter, alternating between the two Agricultural Colleges at Lincoln and Massey, both of which were able to offer accommodation and suitable lecture facilities at a reasonable cost. Following five successful conferences, the Committee sought to encourage participation and attendance from a wider cross section of the public with an interest in learning the latest research into weed control problems. A resolution was passed that future conferences should be held at suitable venues throughout New Zealand (Fig. 1). To date, 19 venues have been used, 28 in the North Island and 22 in the South Island.

\section{Proceedings publication}

A transcript of the initial proceedings was typed on single sided sheets of foolscap paper by a public typist in Christchurch (Table 1). In 1949 the Committee decided "that Conference papers and discussions be cyclostyled, suitably bound and made available at cost price". In addition, the Committee stated that grateful acknowledgment was made "of a donation of 10 guineas from the Agricultural Chemicals Section of Imperial Chemical Industries (NZ) Ltd., to assist in defraying the cost of publication of these

Proc. 50th N.Z. Plant Protection Conf. 1997: 357-363 
pages". With a change in printing location to New Plymouth in 1952, the format changed to a smaller, A5 page size using $70 \mathrm{~g}$ Bank paper (Table 1).

TABLE 1: Printer's location, dates and publication time.

\begin{tabular}{|c|c|c|}
\hline Printers & Years & Time of publication \\
\hline $\begin{array}{l}\text { Reported, transcribed \& cyclostyled, } \\
\text { public typist, Christchurch }\end{array}$ & $1948-51$ & Post conference \\
\hline Taranaki Herald Co Ltd., New Plymouth & $1952-3$ & “ \\
\hline Blundell Bros. Ltd., Wellington & $1954-6$ & “ \\
\hline Wright Carmen Ltd., Wellington & $1957-61$ & “ \\
\hline Sigma Print Ltd., Petone & $1962-72$ & “ \\
\hline Times Commercial Printers, Hamilton & $1971^{1}-7$ & Pre conference \\
\hline Swiftcopy Centre Ltd., Palmerston North & $1978-86$ & “ \\
\hline Swiftprint Centre Ltd., Palmerston North & $1987-97$ & “ \\
\hline
\end{tabular}

${ }^{1}$ Two copies printed (pre and post conference) 1971-5 incl.

The first photograph of a group of delegates at the field day watching a gorse spraying demonstration was included in Volume 5. In an effort to increase participation and membership, Les Matthews suggested the preprinting of the conference proceedings in the early 1970s. The paper grade was changed and heavier weight $90 \mathrm{~g}$ White Bond paper was used from 1978-81. A third change was made in 1982 when the quality was improved to $90 \mathrm{~g}$ Matt Art paper. As the maximum page number per volume was limited, it was decided to make the books more compact by the introduction of the type face reduction from 11 to 8.5 point in 1980. A variety of coloured imitation leather embossed

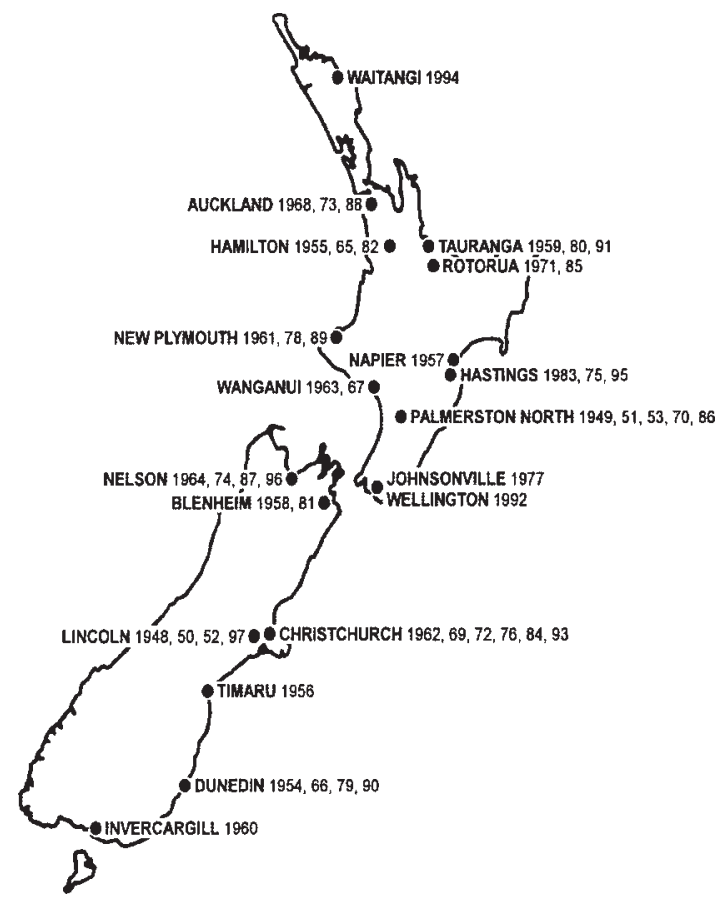

FIGURE 1: Conference venues, sites and years. 
card and front cover designs were used from 1952-86; since that time, a glossy green cover page has become the standard. The Society's first logo was incorporated into the cover design from 1984-95; the following year the design was replaced by the second logo. During the 1960s the proceedings increased in thickness, the mean number of papers and pages doubled from 21 to 40 and 108 to 268 respectively (Fig. 2). Early scientific editorial work was undertaken by the Les Matthews, the Society's Secretary from 1952-1971, whilst Editorial Services Ltd organised the proceedings layout and production from 1962-1972. However, during this time Committee records commented on poor presentation quality and grammatical errors. Instructions for contributing authors were included in 1974 at the back of the front and back cover pages and with modifications in the guidance notes, this continues to the present day.

Editor's position

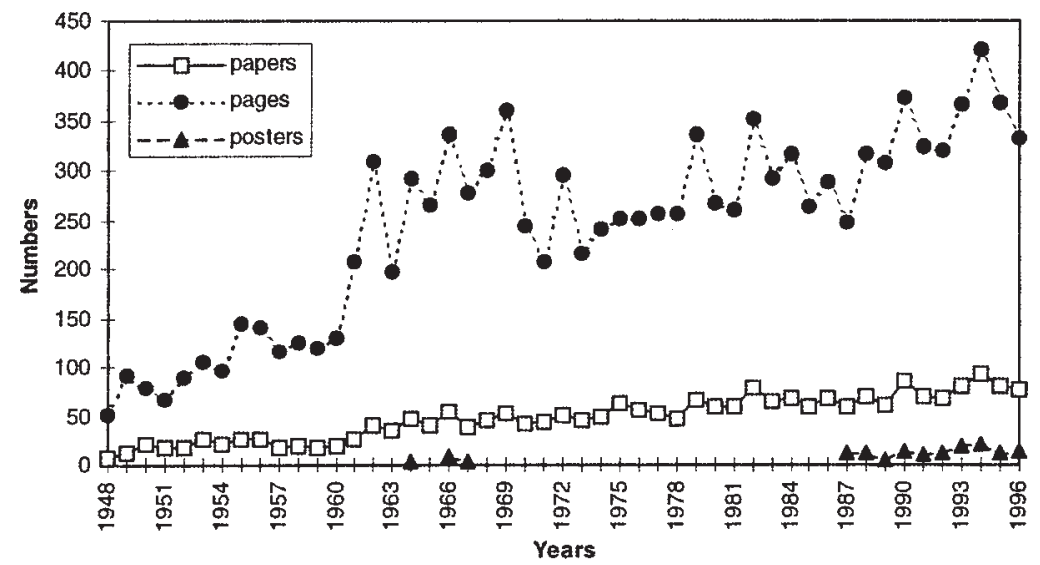

FIGURE 2: Yearly numbers of papers, research notes/posters and total number of pages per volume.

Three women have played an important role within the Society in connection with the yearly publication. All were government scientists in their own right, two based in the North Island at Ruakura and Palmerston North and the third at Lincoln. These changes in location of the editor have been made possible with the use of modern communication technology, electronic email, conference telephone calls etc. The first person with the Society's official title as Editor, was Jennifer Hartley, who completed 13 years continuous service (Table 2). In 1976, an Assistant Editor was appointed to assist with the increase in offered papers. Eight years later, Alison Popay served in this capacity together with her husband Ian, prior to her ten years as Editor. During the 1990s with the introduction of computers, Alison took the Society into the electronic age. Submitted papers were accepted on computer disks in 1992; however, this first year was not without formatting problems associated with an incompatible system at the printers. By the following year Swiftprint had the technology to accept direct disk transfer on their Apple Mac system. Problems have been reported with the introduction of a major electronic system (Miller 1995) and occasional errors occurred with the use of symbols and in table conversion from papers formatted on IBM computers. Once recognised, these errors were quickly corrected and a system set in place whereby the final manuscripts were sent in batches of electronic files in Rich Text Format to the publishers. Recently Maureen O'Callaghan volunteered for the position as the Society's third Editor and is the first to benefit from email with all papers being emailed to the Printer this year.

TABLE 2: Editors and assistant editors, (years in office) from 1973-97 incl. 
Editors

M.J. Hartley, 13 (1973-85)

A.J. Popay, 10 (1986-95)

M. O'Callaghan, 2 (1996-7)
Assistant Editors

J.R. Wilkins, 2 (1976-7)

A.J. Popay, 3 (1983-5)

A.I. Popay, 4 (1984-7)

Computerisation resulted in a considerable financial saving in production costs to the Society. At the beginning of the 1990s, the total yearly publishing costs had risen to an estimated $\$ 18,000$, whilst by 1993 with full use of the new technology the cost of the proceedings was $\$ 11,700$, a $35 \%$ cost reduction (A.J. Popay pers. comm.).

\section{Editorial/Technical Committee}

In 1974, an Editorial Committee was established to assist with the scrutiny of the papers. Over the past 24 years, 62 people have acted as referees on the Technical/ Editorial Panel (Table 3), with a stalwart effort provided by R.C. Close, R. East and A.I. Popay, each recording 16 years service.

TABLE 3: Editorial/ technical committee personnel with more than 4 years of involvement.

\begin{tabular}{llll}
\hline Name & Years & Name & Years \\
\hline B.I.P. Barratt & $14,(1983-7,89-97)$ & G.W. Ivens & $6,(1978-80,82-4)$ \\
G.W. Bourdôt & $14,(1984-97)$ & L.J. Matthews & $5,(1973-7)$ \\
R.S. Buchanan & $8,(1987-94)$ & R.W. Moffat & $13,(1973-9,81-6)$ \\
R.B. Chapman & $12,(1986-97)$ & T.M. Patterson & $7,(1984-91)$ \\
R.C. Close & $16,(1976,1982-96)$ & A.I.Popay & $16,(1982-97)$ \\
R. East & $16,(1978-93)$ & R.A.Prestidge & $7,(1990-5,97)$ \\
R.E. Falloon & $13,(1984-94,96-7)$ & A. Rahman & $14,(1978,83-7,89-97)$ \\
P.G. Fenemore & $10,(1984-93)$ & D. Steven & $5,(1993-7)$ \\
R.E. Gaunt & $10,(1986,88-95,97)$ & D.M. Suckling & $6,(1992-7)$ \\
S.L. Goldson & $12,(1985-95,97)$ & E.A. Upritchard & $5,(1987-910$ \\
M.J. Hartley & $12,(1986-97)$ & C.H. Wearing & $13,(1984,86-97)$ \\
\hline
\end{tabular}

\section{Proceedings layout}

The layout of the yearly proceedings has developed gradually over the first 30 years. Initially the contents page listed the papers, but by 1961 the papers were grouped into sessions on specific topics, e.g., pasture weeds, machinery, chemical ploughing. As the early proceedings were published following the conference (Table 1), it was possible to include the Question and Answer sessions following each paper. This format changed in 1964, with papers grouped by topics followed by the Session Chairman's summaries. Publication costs were reduced with the addition of six to nine single pages of commercial advertisements printed at the back of the proceedings in the 1960s. Later this was reduced to a list acknowledging the support of the contributing organisations and placed on the reverse side of the title page. Since 1955, an index of financial members of the Society has been put at the back of each volume, together with the addition of a list of the Society rules in 1957.

\section{Authors}

The 50 conferences have attracted a total of 2462 papers (which includes 9 keynote and 18 invited papers in 1997) and 179 posters. Many authors regularly submit contributions; F.C. Allen's first paper was in 1949 and he subsequently set a record by contributing papers that spanned 40 years. Five members come into the category of the most prolific authors with papers submitted over a period of 21-30 years (Table 4). C.H. Wearing in 1995, and A.R. Tomkins in 1992 were the two authors with the highest paper output as senior author, with four out of five and four out of four papers respectively. The most contributions at any conference was by the author, G.M. Barker in 1991 with seven papers and three as senior author, whilst in 1994, A. Rahman also recorded seven papers 
with two as senior author. The longest paper was by A.J. Healey with a total of 33 pages in Volume 15, entitled: Dandelions and related rosette weeds in New Zealand. This paper was published 12 years prior to the 2000 word limit set in authors guidance notes in 1974 .

TABLE 4: Most frequent contributors to the proceedings.

\begin{tabular}{lccc}
\hline Name & Publications & $\begin{array}{c}\text { Senior authorship } \\
\text { (Percent of total) }\end{array}$ & $\begin{array}{c}\text { Years of } \\
\text { contributions }\end{array}$ \\
\hline Hartley, M.J. & 51 & $42(82 \%)$ & $25(1972-1996)$ \\
James, T.K. & 54 & $21(39 \%)$ & $21(1977-1997)$ \\
Meeklah,F.A. & 45 & $34(76 \%)$ & $30(1957-1986)$ \\
Popay, A.I. & 41 & $22(54 \%)$ & $21(1975-1995)$ \\
Rahman, A. & 86 & $47(55 \%)$ & $23(1975-1997)$ \\
\hline
\end{tabular}

\section{Other Society publications}

In addition to the 50 yearly conference proceedings, the Society has been responsible for a creditable publication record of books. A total of ten reference books including one designated for general audience and two revised books plus four indices have been published (Table 5). Alan Upritchard's book, A Guide to the Identification of New Zealand common weeds in Colour has been very popular, with 5 reprints and 20,000 copies sold.

\section{TABLE 5: Society's publications.}

\begin{tabular}{|c|c|c|}
\hline Year & Title & Author/Editor \\
\hline 1969 & Standard common names for weeds in New Zealand & A.J.Healy \\
\hline 1969 & $\begin{array}{l}\text { Standard common names for weeds in New Zealand } \\
\text { (Popular Nomenclature) }\end{array}$ & A.J.Healy \\
\hline 1970 & Identification of Weeds and Clovers & A.J.Healy \\
\hline 1974 & Index to Proceedings 1 st to 27 th Conference, $1948-1974$ & \\
\hline 1976 & $\begin{array}{l}\text { Identification of Weeds and Clovers, second edition, } \\
\text { revised }\end{array}$ & A.J.Healy \\
\hline 1980 & Index to Proceedings 1 st to 33rd Conferences $1948-1980$ & \\
\hline 1980 & Weeds of crops and gardens in New Zealand & R.L. Taylor \\
\hline 1980 & Weeds of ponds and streams in New Zealand & R.L. Taylor \\
\hline 1981 & Weeds of roadsides and waste ground in New Zealand & R.L. Taylor \\
\hline 1984 & $\begin{array}{l}\text { Standard common names for weeds in New Zealand } \\
\text { (revised) }\end{array}$ & A.J.Healy \\
\hline 1990 & Index to Proceedings 1st to 43rd Conferences 1948-1990 & \\
\hline 1993 & $\begin{array}{l}\text { A Guide to the Identification of New Zealand common } \\
\text { weeds in Colour }\end{array}$ & E.A. Upritchard \\
\hline 1996 & Pesticide Resistance, Prevention \& Management & $\begin{array}{l}\text { G.W. Bourdot and } \\
\text { D.M. Suckling } \\
\text { (eds) }\end{array}$ \\
\hline 1997 & Index to Proceedings 1 st to 50th Conference $1948-1997$ & \\
\hline 1997 & New Zealand Weeds and Wild Flowers (in prep.) & $\begin{array}{l}\text { B. Roy, A.I.Popay, } \\
\text { P. Champion and } \\
\text { A. Rahman }\end{array}$ \\
\hline
\end{tabular}

\section{Membership}

In the establishment years, the Society's membership rapidly rose to 250 financial members; since then average decade numbers have fluctuated with a $25 \%$ increase from 
the 1970 to 1980 , to reach a peak of 386 (Fig. 3). Initial membership subscription was set at 15 shillings, but with the inclusion of the proceedings for each member, the yearly subscription has gradually risen to keep line with inflation to its present cost of \$55. Membership was split into two categories, with the majority holding the New Zealand membership and just $4 \%$ membership from overseas. The organisation was not intended to appeal solely to a single sex, but early photographs depict the exclusively male participation. A slow change has occurred over the years and by the 50th anniversary the membership of females had reached $16 \%$. In 1968 the Society created the first two Honorary Life Members to acknowledge the significant contribution by L.M. Matthews and D.A. Watkins whose foresight and enthusiasm brought about the first conference. Since then 9 other Honorary Members have been elected: F.B. Thompson (1970), A.J. Healy (1972), P.B. Lynch (1974), F.C. Allen (1976), R.L. Taylor (1981), E.A. Upritchard (1986), W.F. Leonard (1987), M.J. Hartley (1990) and A.J. Popay (1995).

\section{CONCLUSION AND PROSPECTS}

Numerous milestones have been reached during the New Zealand Plant Protection Society's first 50 years in existence. The farmers, agriculturists, agricultural industries and community at large have benefited from the stimulation of presentations and high

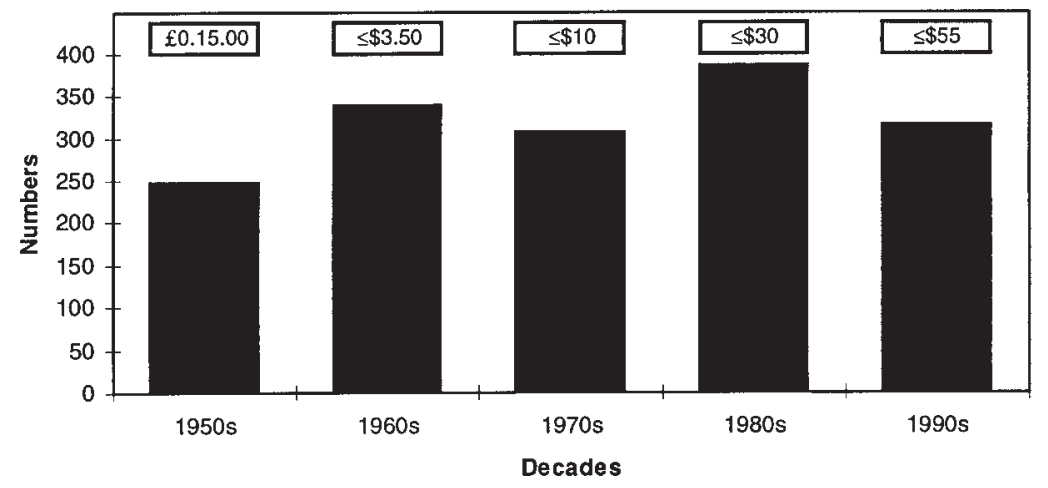

FIGURE 3: Membership and subscription over the decades.

caliber of research findings delivered at the 50 annual conferences. One of the Society's main objectives was to stimulate the publication of current research work. Recognition of the 50 years continuous publication of conference proceedings, the last 27 years of which were pre-printed and circulated prior to each conference, must be made and acknowledged. Behind the scenes, many of the Society's members have given freely of their time and energy to place the New Zealand Plant Protection Society in a strong position to head into the new millennium.

\section{ACKNOWLEDGEMENTS}

I wish to thank Les Matthews for his correspondence with regard to important issues in the establishment of the New Zealand Plant Protection Society. George Zabkiewicz for allowing my perusal of the Society's minute books and membership information. Alison Popay for information on the computer conversion and DowElanco (NZ) Ltd for historical information of their retired Managing Director, Dan Watkins.

\section{REFERENCES}

(1948-97). Proc. 1st-50th N.Z. Plant Prot. Conf.

Miller, M.J., 1995. Getting ready for Windows 95. PC Mag. (14)9: 102-136.

U.S. Joint Purchasing Board, 1945. Food for allied forces, American appreciation.N.Z. 
J. Agric. 70(5): 449.

McKenzie, D.W., ed 1987. New Zealand Atlas, Heinemann Publisher, Auckland.

Robinson, R.H., 1989. Farm tractors in New Zealand, Country Life (NZ) Ltd., Ngonotaka, N.Z. 